\title{
A Cost-Effectiveness Analysis of Seminatural Wetlands and Activated Sludge Wastewater-Treatment Systems
}

\author{
Ilda Mannino - Daniel Franco - Enrico Piccioni - Laura Favero • \\ Erika Mattiuzzo • Gabriele Zanetto
}

Received: 15 December 2006/Accepted: 19 May 2007/Published online: 18 October 2007

(C) Springer Science+Business Media, LLC 2007

\begin{abstract}
A cost-effectiveness analysis was performed to evaluate the competitiveness of seminatural Free Water Surface (FWS) wetlands compared to traditional wastewater-treatment plants. Six scenarios of the service costs of three FWS wetlands and three different wastewater-treatment plants based on active sludge processes were compared. The six scenarios were all equally effective in their wastewater-treatment capacity. The service costs were estimated using real accounting data from an experimental wetland and by means of a market survey. Some assumptions had to be made to perform the analysis. A reference wastewater situation was established to solve the problem of the different levels of dilution that characterize the inflow water of the different systems; the land purchase cost was excluded from the analysis, considering the use of public land as shared social services, and an equal life span for both seminatural and traditional wastewater-treatment plants was set. The results suggest that seminatural systems are competitive with traditional biotechnological systems, with an average service cost improvement of 2.1 -fold to 8 -fold, according to the specific solution and discount rate. The main improvement factor was the lower maintenance cost of the seminatural systems, due to the self-regulating, low artificial energy inputs and the absence of waste to be disposed. In this
\end{abstract}

\footnotetext{
I. Mannino

Venice International University, Isola di San Servolo, Venice 30100, Italy

D. Franco $(\bowtie) \cdot$ E. Piccioni - L. Favero - E. Mattiuzzo

Planland-Studio Tecnico Daniel Franco, Cannaregio 3841,

Venice 30131, Italy

e-mail: studio@danielfranco.org

G. Zanetto

Università Cà Foscari, Dorsoduro 3246, Venice 30123, Italy
}

work, only the waste-treatment capacity of wetlands was considered as a parameter for the economic competitiveness analysis. Other goods/services and environmental benefits provided by FWS wetlands were not considered.

Keywords Cost-effectiveness analysis .

Free water surface wetlands - Service cost .

Wastewater treatment

\section{Introduction}

Wetland assimilation provides the same services as conventional methods in improving wastewater quality when used to provide advanced secondary and tertiary treatment (Breaux and others 1995; Ko and others 2004). Wetlands are particularly efficient for the removal of suspended solids and nutrients (Boustany and others 1997; Breaux and Day 1994; Day and others 2003; Ewel and Odum, 1984; Kadlec and Knight 1996; Nichols, 1983; Zhang and others 2000), biochemical oxygen demand (BOD), chemical oxygen demand (COD), and pathogens (Mitsch and Gosselink 2000; Nokes and others 1999; Wood, 1995). It is now recognized that constructed wetlands can provide an improvement in landscape diversity and a valuable habitat for waterfowl and other wildlife, as well as areas for public education and recreation (USEPA 1993).

In comparison with wastewater-treatment plants, a seminatural wetland involves low construction and maintenance costs over the long term, does not consume nonrenewable energy, and does not produce sludge to be disposed.

Constructed wetlands are generally used for treating domestic wastewater, for improving the quality of the water bodies, or as secondary and even tertiary treatment 
(Avsar and others 2007). On the other hand, traditional wastewater-treatment systems are designed to treat highly concentrated wastewaters: they remove pollutants from concentrated wastewater more efficiently than wetland systems.

For some kinds of wastewater (e.g., diluted waters), natural systems are as effective as traditional wastewatertreatment plants in terms of depuration, but with a lower environmental impact. For example, Italian government legislation suggests the use of wetland systems to treat wastewater for urban agglomerates with less than 2000 inhabitants (e.g., D.L.vo n. 152 1999).

Traditional plants, like all other industrial plants, consume energy and produce waste (Breaux and others 1995; Mitsch and Gosselink 2000; Viessman and Hammer 1998; Tchobanoglous and Burton 1991). Natural systems can therefore represent a virtually expense-free alternative to other technological wastewater-treatment processes (Breaux and others 1995; Cardoch and others 2000; Ko and others 2004; Steer and others 2003).

A monetary comparison of different kinds of plant is rarely made, despite the fact that minimization of costs is often indicated by government legislation as a priority (D.L.vo n. 152 2006).

The aim of this work was to compare the economic benefit of a phytodepuration system [Free Water Surface (FWS) wetland] with that of traditional wastewater-treatment plants, for wastewater that can be treated in both these kinds of system. The economic benefit was assessed on the basis of surface wastewater-treatment functions for the purposes of this study. The assessment was performed with a cost-effectiveness analysis.

\section{Materials and Methods}

Monetary or nonmonetary methods can be used to perform a comparison of different technologies. These methods assign a preference ranking based on qualitative parameters and a "social" weight for some judgment criteria. Monetary methods refer to the cost-benefit analyses, where benefits are the goods/services produced (or saved) and costs are the goods/services consumed in development of the project.

When there are difficulties in assigning a monetary value to the benefits, a cost- effectiveness analysis can be used (Anderson 1998; Gudger and Barker 1993; Hanley and Spash 1993; Heinzerling and Ackerman 2002; Pearce et al. 2006; Wheeler 1998; Willan and Briggs 2006). Based on defining the threshold effectiveness value, the costeffectiveness analysis estimates the costs needed to reach it, and the benefit is maximised when the fixed goal is reached at the minimum cost.
Surface water and wastewater treatment is a benefit that is normally described in quantitative or chemical terms. In this case, the cost necessary to reach a threshold of (depuration) effectiveness was considered to obtain an economic benefit evaluation. This cost was estimated as the "service cost," defined as the total cost charged by a plant over a certain period relative to the service offered to the taxpayer or customer.

The economic and efficiency data for the seminatural FWS treatment wetlands were obtained by a 3 -year monitoring of a real experimental plant.

\section{The Experimental Treatment Wetland}

The Canale Nuovissimo Ramo Abbandonato phytodepuration system is an experimental FWS wetland defined as seminatural, designed and built to minimize the input of exogenous matter and to minimize the time lag of the wet ecosystem's stabilization to a self-regulating and steady state. It was constructed in the Venice Lagoon watershed (Italy) to verify the efficiency of these systems in the treatment of water entering the lagoon.

The water entering the system comes from a reclaimed agricultural channel and is characterized by non-pointsource agricultural and urban pollution. The system is brackish because of the influence of the Venice Lagoon. The wetland was created in a reclaimed lowland delta, currently below sea level, using an abandoned channel. There are no differences in hydraulic head across the wetland; therefore, pumps are used to circulate surface water through the wetland. The wetland is $50 \mathrm{~m}$ wide and $4.14 \mathrm{~km}$ long with a mean depth of $80 \mathrm{~cm}$ and was divided into three subsystems of differing morphology and vegetation. The first ecosystem is a meandering riparian swamp ecosystem dominated by hydrophytic trees and shrubs. The second ecosystem is a wet riparian ecosystem. The channel is linear, and one-third of the area of emergent plants consisted of trees and shrubs, whereas the remaining area is covered by marsh vegetation. Finally, the third ecosystem is a marsh ecosystem, with shrubs and trees playing an ancillary role (slope protection, habitat). Vegetation for restoring the three ecosystems was chosen in agreement with the phytosociological classification of the transitional zone between the mainland and the Venice Lagoon. Construction of the first and part of the second ecosystems required extensive modification of the original conditions, which was achieved by adding agricultural soil to the previous channel banks.

The design (1999-2001), construction (2002), and monitoring (ongoing) of the experimental system were funded by the Ministry of Infrastructures-Venice Water Authority through its concessionary, Consorzio Venezia Nuova. 
Table 1 Percent abatement of the pollutant (kg removed on input kg) during the steady-state regime (April 14, 2004 to April 15,2005), and the daily inputs of the principal pollutants of the experimental wetland

\begin{tabular}{|c|c|c|c|c|c|c|c|}
\hline & Suspended solids & Total P & $\mathrm{N}-\mathrm{NH}_{4}$ & $\mathrm{~N}-\mathrm{NO}_{3}$ & Total $\mathrm{N}$ & BOD & COD \\
\hline$\%$ Abatement ( $\mathrm{kg}$ removed on input $\mathrm{kg}$ ) & 57.09 & 43.82 & 71.7 & 86.28 & 59.35 & 12.04 & 39.53 \\
\hline Daily input (g/day) & 484 & 49 & 4,167 & 120 & 8,604 & 7,568 & 31,385 \\
\hline
\end{tabular}

Finding the Depuration Effectiveness Threshold

A step procedure was followed to set the depuration effectiveness threshold.

\section{Finding the Reference Parameters for the Effectiveness Threshold}

The period to set the abatement rate of the experimental system (Table 1) was chosen on an annual basis, hence the restored wetland approximated to a steady state after the first stabilization period (Anderson and others 2005; Kadlec and Knight 1996;). The reduction in the pollutant loading rate was comparable with data in the literature regarding secondary wastewater-treatment wetlands (e.g., Breaux and others 1995). A further period was not undertaken because it would not have been concluded during this research. Moreover, further results confirmed the abatement rate.

The components of a traditional wastewater-treatment system were determined starting from the inflow sewage characteristics defined quantitatively, as per capita water supply and the number of Equivalent Inhabitants (EI), ${ }^{1}$ and qualitatively, as the daily load of pollutants. In this case, with the wetland inflow and outflow rates being equal (gauged during monitoring), the EI number $(12,975)$ was deduced from the mean daily flow rate of the experimental wetland $\left(2595 \mathrm{~m}^{3} /\right.$ day $)$.

\section{Finding the Reference Wastewater for the Effectiveness Threshold}

Sewage with the same EI was set from the mean daily flow rate of the experimental wetland. Sewage likely to be treated by a hypothetical wastewater disposal plant (fed by point and not a diffused pollution source) should be characterized by input concentrations higher than those of the experimental wetland inflow (Table 1).

\footnotetext{
1 The Equivalent Inhabitant is used as one of the parameters for the organic load of waste water and is equal to an Oxygen Chemical Demand of $130 \mathrm{~g} \mathrm{day}^{-1}$ or a discharge volume of $2001 \mathrm{day}^{-1}$, whichever as higher (Art. 4, c.1, L.R.T. n. 5/86).
}

Table 2 Estimation of the reference wastewater characteristics based on Equation 1

\begin{tabular}{lllr}
\hline Pollutant $(i)$ & $A_{i}(\mathrm{mg} / \mathrm{L})$ & $B_{i}(\%)$ & $C_{i}(\mathrm{mg} / \mathrm{L})$ \\
\hline Suspended solids & $\leq 80$ & 57.09 & 186.00 \\
Total P & $\leq 10$ & 43.82 & 3.57 \\
$\mathrm{~N}^{-N_{4}}$ & $\leq 15$ & 71.70 & 53.60 \\
$\mathrm{~N}_{4}$ & $\leq 20$ & 86.28 & 143.00 \\
BOD & $\leq 40$ & 12.04 & 45.45 \\
COD & $\leq 160$ & 39.53 & 266.67 \\
\hline
\end{tabular}

$A_{i}=$ Surface water spillage limits (Italian law, DLgs 152/99); $B_{i}=$ abatement effectiveness (experimental FWS wetland); $C_{i}=$ input concentration (hypothetical wastewater)

To remedy difficulties in comparison with the literature, due to the dilution of the reclaimed waters treated by the experimental wetlands, a hypothetical reference wastewater value was set by making some assumptions. The reference wastewater was obtained by using the input loads of the annual abatement rate of the experimental wetland, taking account of the law enforcement limits for surface water spillage (Table 2), by means of

$C_{i}-\left(B_{i} \times C_{i}\right)=A_{i}$

where $C_{i}$ is the concentration of the $i$ pollutant in the hypothetical wastewater to be treated, $B_{i}$ is the wetland abatement rate of the $i$ pollutant, and $A_{i}$ is the law limit concentration for spillage of the $i$ pollutant in the surface waters. The loading abatement percentage was used to calculate the reference concentration because a constant was set for the wetland flow rate.

The implicit assumption of Equation 1 took into account that the abatement processes follow a first-order kinetics in the presence of concentrations equal to or higher than that set as the threshold. These assumptions were admissible because in the treatment wetlands, the abatement percentage tends to increase with input concentration, following first-order kinetics (Kadlec and Knight 1996; Rousseau and others 2004), and this behavior was also ascertained for the experimental wetland.

For these reasons, the input concentrations of the reference wastewater, higher than those registered for the experimental wetland, should be abated in an equivalent or better way in treatment wetlands than the monitored one. 
Table 3 Literature data for the input pollutant concentration and abatement rates compared to the experimental FWS wetland and to the hypothetical reference wastewater

\begin{tabular}{|c|c|c|c|c|}
\hline Reference & Concentration in $(\mathrm{mg} / \mathrm{l})$ & Concentration out (mg/l) & $\%$ abatement & Notes \\
\hline \multicolumn{5}{|l|}{ Total P } \\
\hline Braskerud 2005a, 2005 b & $<2,15$ & & & First-order kinetics described \\
\hline Kadlec and Knight 1996 & 3.78 & & 57 & First-order kinetics described \\
\hline Knowlton and others 2002 & 2.1 & 2 & 4 & \\
\hline \multirow[t]{3}{*}{ USEPA 2001} & 28.4 & 6.8 & 76.1 & \\
\hline & 25.3 & 10.8 & 57 & \\
\hline & 33 & 17 & 48 & \\
\hline ITRC 2003 & 4 & & 48 & \\
\hline \multicolumn{5}{|l|}{ Suspended solids } \\
\hline \multirow[t]{4}{*}{ USEPA 2001} & 135.7 & 15.5 & 88.6 & \\
\hline & 483.4 & 113.2 & 77 & \\
\hline & 1596 & 48 & 97 & \\
\hline & 542 & 142 & 74 & \\
\hline Nyakang'o and Van Bruggen 1999 & $200-600$ & 70 & 85 & \\
\hline \multicolumn{5}{|l|}{ BOD-COD } \\
\hline Dass 2004 & $50-200$ & & $80-95$ & BOD and COD \\
\hline ITRC 2003 & $20-100$ & & $67-80$ & BOD \\
\hline \multirow[t]{2}{*}{ Nyakang'o and Van Bruggen 1999} & $500-750$ & 20 & 98 & BOD \\
\hline & $800-1000$ & 20 & 96 & COD \\
\hline \multicolumn{5}{|l|}{$\mathrm{N}-\mathrm{NH}_{4}$} \\
\hline Kadlec and Knight 1996 & $<20$ & & 54 & \\
\hline \multirow[t]{4}{*}{ USEPA 2001} & 55.6 & 8.6 & 84.5 & \\
\hline & 199.4 & 99.8 & 50 & \\
\hline & 12 & 2.4 & 80 & \\
\hline & 126 & 65 & 48 & \\
\hline ITRC 2003 & 230 & & 91 & \\
\hline Nyakang'o and Van Bruggen 1999 & $60-80$ & 10 & 90 & \\
\hline \multicolumn{5}{|l|}{$\mathrm{N}-\mathrm{NO}_{3}$} \\
\hline Jordan 2003 & $<1$ & & & First-order kinetics described \\
\hline Kovacic 2000 & $7.5-14.5$ & & $25-99$ & \\
\hline Lorion 2001 & $100-150$ & 10 & & \\
\hline
\end{tabular}

Even though Rousseau and others (2004) highlighted that over a certain concentration threshold, the wetlands abatement capacity decreases and is no longer described by first-order kinetics; all of the recorded data and the set reference limits (Table 2) were below that threshold. A review of cases in the literature was used to assess the above assumptions (Table 3).

Even for total $\mathrm{P}$ or for suspended solids (SS) the review data confirmed the capacity of FWS wetland to abate the upper limits of concentration hypothesized and explained by first-order kinetics (Braskerud and others 2005a, 2005b; Interstate Technology \& Regulatory Council (ITRC) 2003; USEPA 2001; Kadlec and Knight 1996). In the case of BOD and COD, it seems that the abatement capacity is independent of input concentration, yet very efficient for higher or lower values than those set here (Dass and others 2004; ITRC 2003; Nyakang'o and Van Bruggen 1999).

In the case of ammonium and nitrate, the hypothesized input concentrations did not exceed the first-order abatement kinetics reported in the selected literature (ITRC 2003; Jordan 2003; USEPA 2001; Kadlec and Knight 1996; Kovacic 2000; Mitsch and others 2005).

Therefore, for all of the parameters monitored in the FWS wetland, the literature analyzed reported (1) the presence of a first-order abatement kinetic and (2) that input concentrations equal or higher than the hypothesized ones allow an abatement that is equal to or higher than those monitored in the experimental wetland. 
Finding the Comparable Traditional Technologies

Having defined the reference wastewater (Table 2), the best traditional wastewater-treatment solution to meet the effectiveness threshold was identified through a market survey. A representative sample of specialized companies was asked to make a detailed preproposal for the construction of a treatment system, including a quantitative and qualitative description of the wastewater. The preproposal had to be presented as cost categories (setup, ordinary maintenance, special maintenance) and equipped with detailed technical reports on the adopted solutions.

The companies contacted were divided into two groups. The first control group of eight companies (Group A) received information on the real aim of the request, the reference wastewater definition method, and the characteristics of the FWS experimental wetland. This group was then asked to make the best technical preproposal for the best available plant. The second group of 12 companies was not told the real aim of the request, only given the specifics of the reference wastewater.

In this way it was possible to make a comparative evaluation of the information obtained from a different market survey approach. The results were essentially similar for the companies that gave a positive/useful reply (11 cases). The reply that gave the most detailed and exhaustive information was selected to define the best available plant, which was a completely automated technological plant based on activated sludge processing of secondary treated sewage. The process comprised several stages: sewage arrival and pumping, predenitrification, nitrification, sedimentation, sludge recirculation, sludge settling, and decanting. The market survey also allowed the parameters of frequency and costs of ordinary and extraordinary maintenance to be specified for the set life span (20 years).

In the plant thus obtained, the sewage was pumped into the predenitrification tanks to transform nitrates into gaseous nitrogen. During nitrification, the ammonium and organic matter were oxidized. The ammonium was removed in an aerobic environment using a bacteria-driven process supported by forced oxidation. The aerated mixture was routed to the sedimentation stage, where particles with a higher specific weight than water were separated by gravity. The disposed activated sludge was partly recirculated to maintain an optimal bacterial level in the plant and partly disposed and/or treated in the agricultural or composting sectors, if not classified as waste. To reduce the maintenance costs, a dehydrator could be installed, which reduces the volume of disposable sludge.

The plant was designed to be proportioned to comply with the legal limits used in Equation 1 (Table 2). It was made of two subdivided blocks $(25 \times 20 \times 4.5 \mathrm{~m})$ and a circular $(15 \mathrm{~m}$ in diameter $\times 2.5 \mathrm{~m}$ high) concrete tank. The electromechanical system consisted of two electric pumps for the sewage pumping, one submerged blender for the denitrification tank one submerged aerator for the nitrification tank, one submerged pump for water-sludge blend circulation, one adapted overhead traveling crane for the sedimentation stage, two submerged pumps for sludge recirculation, one electrical panel, an electrical system, and a hydraulic system for the plant connections.

\section{Finding the Plant and Cost Categories to be Compared}

The economic and technical data, monitored during the construction and operational phytodepuration of the experimental wetland, were gathered into development cost and maintenance cost categories to facilitate the comparison of operational phytodepuration and traditional wastewater-treatment systems. Moreover, only the costs that differentiate the water-treatment technologies were considered; therefore, the inflow and outflow connection costs to the final receptor, which are common to both approaches, were excluded.

\section{FWS Wetlands}

Costs. The monitoring system of the Canale Nuovissimo experimental phytodepuration plant corresponds to cost categories that do not exist in a normal FWS treatment wetland. Therefore, monitoring system costs were not included in this study.

In the development category, the costs actually considered accounted for planting, the addition of soil and shaping of banks, service road construction, pumping stations, the electrical system, and electric connections. The purchase of the land was not accounted for in this category. This item could have potentially added to the service costs, particularly compared to traditional technological treatment plants, which take up much less land. It was assumed that the FWS wetland treatment systems are at least partially built on public land, in order to deal with water purification or provide social benefits linked to restoration (Healy and Cawley 2002; ITRC 2003;Knowlton and others 2002; Yang and others 2006). Another reason was the extreme uncertainty of this item. The cost of the land needed to build the FWS could vary markedly from place to place, although it is generally lower than that of land suitable for traditional wastewater-treatment plants. First, the remaining lowlands are problematical from an urban, industrial, or commercial point of view; and second, there are stronger technological and utility connection constraints for the 
Table 4 Cost descriptions for the selected and equally effective FWS treatment plants

\begin{tabular}{|c|c|c|c|c|}
\hline Cost category & Cost description & WA $(€)$ & WB $(€)$ & $\mathrm{WC}(€)$ \\
\hline \multirow[t]{5}{*}{ Development $\left(C_{i}\right)$} & Addition of soil and shaping of banks & $1,096,276.50$ & $1,218,085.00$ & $1,218,085.00$ \\
\hline & Electrical system, electric connections & & & $16,113.00$ \\
\hline & Inflow pumping station & & & $118,992.00$ \\
\hline & Outflow pumping station & & & $97,200.00$ \\
\hline & Plantation & $297,247.00$ & $297,247.00$ & $297,247.00$ \\
\hline Subtotal $\left(C_{i}\right)$ & & $1,393,523.50$ & $1,515,332.00$ & $174,7637.00$ \\
\hline \multirow[t]{2}{*}{ Ordinary maintenance $\left(C_{\mathrm{GO}}\right)$} & Plantation management care & $34,008.69$ & $34,008.69$ & $34,008.69$ \\
\hline & Maintenance of pump station and utilities & & & $134,278.80$ \\
\hline Subtotal $\left(C_{\mathrm{GO}}\right)$ & & $34,008.69$ & $34,008.69$ & $168,287.49$ \\
\hline Extraordinary maintenance $\left(C_{\mathrm{GS}}\right)$ & Harvesting and regeneration of the wetland wood & $40,000.00$ & $40,000.00$ & $40,000.00$ \\
\hline Subtotal $\left(C_{\mathrm{GS}}\right)$ & & $40,000.00$ & $40,000.00$ & 40000.00 \\
\hline Total & & $1,467,532.19$ & $1,589,340.69$ & $1,955,924.49$ \\
\hline
\end{tabular}

$\mathrm{WA}=$ wetland, which includes as cost: plantation, addition of soil and shaping of banks, plantation management care, harvesting and regeneration costs; $\mathrm{WB}=$ wetland, which include as cost: plantation, addition of soil and shaping of banks, service road construction, plantation management care, harvesting and regeneration costs; $\mathrm{WC}=$ wetland, which include as cost: plantation, addition of soil and shaping of banks, service road construction, pumping stations, electrical system and connections, plantation management care, maintenance of pump station and utilities, and harvesting and regeneration costs

site selection. Plantation management care (mowing; replanting, only during the first 3 years) and maintenance of the pump stations were part of the ordinary maintenance cost category. Harvesting and regeneration of the wetland wood were part of the extraordinary maintenance cost category. The discounting back of this cost was set at 20 years; no incomes were considered.

Plants. Three realistic cost scenarios corresponding to three realistic FWS plants (WA, WB, WC) of equivalent abatement capacity were estimated, using single cost invoice accounting in each of the cost categories. The three plant scenarios were differentiated on the basis of increasing costs, according to realistic design and development constraints, like shaping necessities or accessing utilities or water supply (gravity or mechanical feed). The three set plants are shown on a scheme of cost subdivisions (Table 4).

Development costs. For subdivision WA: plantation, addition of soil and shaping of banks; for subdivision WB: plantation, addition of soil and shaping of banks, service road construction; for subdivision WC: plantation, addition of soil and shaping of banks, service road construction, pumping stations, electrical system and connections.

Ordinary maintenance costs. For subdivision WA: plantation management care; for subdivision WB: plantation management care; for subdivision WC: plantation management care, maintenance of pump stations and utilities.

Extraordinary maintenance costs. For subdivision WA: harvesting and regeneration costs; for subdivision WB: harvesting and regeneration costs; for subdivision WC: harvesting and regeneration costs.

\section{Traditional Wastewater Treatment Plant}

Costs. In the case of technological sewage disposal, the land purchase cost was excluded. We excluded the primary treatment costs, considering that the inflow wastewater to the experimental wetland was not pretreated and to maintain a rationale in the comparisons. The selected development costs were (1) construction of concrete tanks, (2) delivery and installation of the electric-mechanical devices, (3) plant automation, and (4) possible delivery and installation of a mechanical dehydrator. The fixed ordinary maintenance costs were (1) technical maintenance of the constructed and electric-mechanical devices, (2) analytical and technical management, (3) electrical energy use; and (4) final sludge disposal.

It was assumed in the first instance that the final sludge (solid or liquid) was free of toxic elements and not classified as waste (therefore usable in the agricultural sector according to European, Italian, and local body laws) and considering the cost of disposal as the cost of transport to the final destination. Therefore, the dehydrator development cost allows for a decrease in the ordinary maintenance costs, reducing the final sludge volume and the number of transport journeys for its disposal/treatment. In this case (dewatered sludge), the 
final sludge could be transported to a composting plant, but with a charge for the management company.

The high uncertainty of extraordinary maintenance requirements was simplified by assuming these costs to correspond to further maintenance costs (replacement of electric-mechanical devices) at fixed deadlines.

Plant. Three possible technological solutions could be used for comparisons depending on the sludge disposal modality: (1) with a mechanical dehydrator and agricultural sludge use; (2) without mechanical dehydrator and agricultural disposal; (3) with mechanical dehydrator and transport for composting (solid sludge only).

To determine the comparisons between equally effective alternative plants, the three technological solutions were combined with three transport distance ranges, giving seven possible solutions: TA, liquid sludge-disposal within $0 \mathrm{~km}$; TB: liquid sludge — disposal within $25 \mathrm{~km}$; TC: liquid sludge—disposal within $50 \mathrm{~km}$; TD: solid sludge — disposal within $0 \mathrm{~km}$; TE: solid sludgedisposal within $25 \mathrm{~km}$; TF: solid sludge-disposal within $50 \mathrm{~km}$; TG: solid sludge—composting.

\section{Service Cost}

The service cost $\left(\mathrm{C}_{\mathrm{s}}\right)$ was defined as the total cost needed to give an annual wastewater-treatment service per EI over the life span of the plant.

The econometric model used was (Tomasinsig and others 2000):

$C s=\left(A_{I}+C_{G O}+A_{G S}\right) / \mathrm{EI}$,

where

$A_{I}=C_{I} i(1+i) t /[(1+i) t-1]$,

$A_{G S}=C_{G S}^{\prime}(1+i)-t^{\prime} i(1+i) t /[(1+i) t-1]$

$C_{s}$ is the service cost, $A_{I}$ is the annual refund rate of the plant cost, $C_{I}$ is the development cost, $C_{\mathrm{GO}}$ is the ordinary maintenance cost, $A_{\mathrm{GS}}$ is the annual refund rate of the present value of the extraordinary maintenance cost, $C^{\prime}{ }_{\mathrm{GS}}$ is the ordinary maintenance cost at the $t^{\prime}$ moment, $t$ is the plant life span, $t$ ' is the discounting back of ordinary maintenance expenses, and $i$ is the discount rate.

\section{Plant Life Span and Discount Rate}

The life span of all the compared plants was set at 20 years, determined as the mean period over which the capacity and the abatement effectiveness of the plants could become obsolete. This is indeed unlikely for the seminatural treatment wetlands (Black and Wise 2003, Craft and others 2002; Hefting and others 2006; Mitsch and others 2005), but quite probable for the traditional wastewater-treatment plants.

It was assumed that during this period, maintenance would be regularly and correctly carried out, maintaining the set wastewater-treatment effectiveness. The discount rate is generally higher in the case of higher development and maintenance investments and, in any event, influences the final results of the econometric model (Equation 2).

A sensitive analysis was made of the discount rate influence using a $5 \%$ or a $10 \%$ rate, values generally associated with the estimation of wastewater-treatment plant performances (Breaux and others 1995; Steer and others 2003).

Finally, in order to show which system is more economic, the service costs of three different seminatural systems (with increasing context limits and investment necessities) were compared with three different traditional wastewater-treatment plants (selected from the most economically viable according to the type of sludge disposal) equally effective in their wastewater-treatment capacity.

\section{Results}

The three selected FWS wetland-treatment plants were equally effective in terms of wastewater-treatment capacity, but at increasing costs (see Materials and Methods section). Their costs, for each cost category, are defined in Table 4. The same scheme was used for the traditional wastewater plant (Table 5). All maintenance costs were based on a 20-year plant life span. The estimate implementation in the econometric model (Equation 2) easily produced a first comparison for each equivalent plant at each discount rate (Fig. 1).

FWS seminatural wetland presented a development cost ranging from $€ 1,393,523.00$ to $€ 1,747,637.00$, whereas traditional wastewater-treatment plants range from $€ 200,000.00$ to $€ 250,000.00$ (Tables 4 and 5 and Figure 1).

The development conditions were inverted compared to the ordinary maintenance costs (Figure 1), which showed unquestionably higher values, even for the less expensive traditional water-treatment solutions (without mechanical dehydrator and disposal on annexed agricultural areas). Generally, the disposal of solid sludge (with dehydrator) was less expensive than for the liquid form, but when all of the cost items were considered, the solid sludge option was only appropriate if the disposal site was further than $50 \mathrm{~km}$ from the site (Table 5). The absence of the dehydrator decreased the ordinary maintenance costs for the other threshold distances considered $(0$ and $25 \mathrm{~km})$. A distance of 
Table 5 Cost descriptions of the selected and equally effective technological treatment plants

\begin{tabular}{|c|c|c|c|c|c|c|c|c|}
\hline Cost category & Cost description & TA1 $(€)$ & TB1 (€) & TC1 $(€)$ & TD1 $(€)$ & TE1 (€) & TF1 (€) & TG1 (€) \\
\hline \multirow[t]{4}{*}{ Development $\left(C_{i}\right)$} & $\begin{array}{c}\text { Construction of } 2 \\
\text { concrete tanks }\end{array}$ & $85,000.00$ & $85,000.00$ & $85,000.00$ & $85,000.00$ & $85,000.00$ & $85,000.00$ & $85,000.00$ \\
\hline & $\begin{array}{l}\text { Delivery and } \\
\text { installation of } \\
\text { the electric- } \\
\text { mechanical } \\
\text { devices }\end{array}$ & $95,000.00$ & $95,000.00$ & $95,000.00$ & $95,000.00$ & $95,000.00$ & $95,000.00$ & $95,000.00$ \\
\hline & Plant automation & $20,000.00$ & $20,000.00$ & $20,000.00$ & $20,000.00$ & $20,000.00$ & $20,000.00$ & $20,000.00$ \\
\hline & $\begin{array}{l}\text { Delivery and } \\
\text { installation of } \\
\text { a mechanical } \\
\text { dehydrator }\end{array}$ & & & & $50,000.00$ & $50,000.00$ & $50,000.00$ & $50,000.00$ \\
\hline Subtotal $\left(C_{i}\right)$ & & $200,000.00$ & $200,000.00$ & $200,000.00$ & $250,000.00$ & $250,000.00$ & $250,000.00$ & $250,000.00$ \\
\hline \multirow[t]{4}{*}{$\begin{array}{l}\text { Ordinary } \\
\quad \text { maintenance }\left(C_{\mathrm{GO}}\right)\end{array}$} & $\begin{array}{l}\text { Technical } \\
\text { maintenance }\end{array}$ & $300,000.00$ & $300,000.00$ & $300,000.00$ & $420,000.00$ & $420,000.00$ & $420,000.00$ & $420,000.00$ \\
\hline & $\begin{array}{l}\text { Analytical and } \\
\text { technical } \\
\text { management }\end{array}$ & $108,000.00$ & $108,000.00$ & $108,000.00$ & $108,000.00$ & $108,000.00$ & $108,000.00$ & $108,000.00$ \\
\hline & $\begin{array}{l}\text { Energy } \\
\text { consumption }\end{array}$ & $360,000.00$ & $360,000.00$ & $360,000.00$ & $375,000.00$ & $375,000.00$ & $375,000.00$ & $375,000.00$ \\
\hline & $\begin{array}{l}\text { Final sludge } \\
\text { disposal }\end{array}$ & 0.00 & $120,000.00$ & $240,000.00$ & 0.00 & $22,500.00$ & $45,000.00$ & $288,000.00$ \\
\hline Subtotal $\left(C_{\mathrm{GO}}\right)$ & & $768,000.00$ & $888,000.00$ & $1,008,000.00$ & $903,000.00$ & $925,500.00$ & $948,000.00$ & $1,191,000.00$ \\
\hline $\begin{array}{l}\text { Extraordinary } \\
\quad \text { maintenance }\left(C_{\mathrm{GS}}\right)\end{array}$ & & $40,000.00$ & $40,000.00$ & $40,000.00$ & $40,000.00$ & $40,000.00$ & $40,000.00$ & $40,000.00$ \\
\hline Subtotal $\left(C_{\mathrm{GS}}\right)$ & & $40,000.00$ & $40,000.00$ & $40,000.00$ & $40,000.00$ & $40,000.00$ & $40,000.00$ & $40,000.00$ \\
\hline Total & & $1,008,000.00$ & $1,128,000.00$ & $1,248,000.00$ & $1,193,000.00$ & $1,215,500.00$ & $1,238,000.00$ & $1,481,000.00$ \\
\hline
\end{tabular}

TA1: liquid sludge—disposal within $0 \mathrm{~km}$; TB1: liquid sludge—disposal within $25 \mathrm{~km}$; TC1: liquid sludge—disposal within $50 \mathrm{~km}$; TD1: solid sludge_disposal within $0 \mathrm{~km}$; TE1: solid sludge—disposal within $25 \mathrm{~km}$; TF1: solid sludge—disposal within $50 \mathrm{~km}$; TG1: solid sludge— composting

less than $50 \mathrm{~km}$ was never economic for disposal of the solid sludge as compost.

The estimated extraordinary maintenance costs were substantially equivalent.

Considering all possible plants, the discount rate increase had a primary influence on the initial investment and a secondary one on the extraordinary maintenance expenses (Figure 1). Independent of the discount rate, the FWS wetland service cost was always lower than that of traditional water treatment plants.

Finally, to select the most economic traditional treatment solution from the seven selected (Table 5) for the effectiveness cost analysis, we dealt with the service cost by the traveling distance for the sludge disposal using a 5\% or $10 \%$ discount rate (Figure 2). The discount rate had a small influence on the critical transport threshold and on the final service cost, and the travel intensity remained the determining variable for economic performance and as a technological solution. If the distance from the agricultural disposal site ranged from 35.64 to $320 \mathrm{~km}(i=5 \%)$ or from 36.12 to $320 \mathrm{~km}(i=10 \%)$, the sludge dewatering solution was always the most economical. For greater distances or in the case of agricultural disposal not being feasible, the most economic option would be disposal by composting.

\section{Discussion}

\section{Development Cost}

The results showed that the development cost of the FWS seminatural wetland was sixfold to ninefold higher than traditional technological treatment plants (Tables 4 and 5 and Figure 1). This is because technological treatment plants are based on standardized technology, meaning that the construction elements are predetermined, furnished with all necessary facilities and easy to supply and install, and the design and production are highly standardized. All of these elements produce an economy of scale with direct effects on sale prices.

Despite the low technological investment, phytodepuration plants, particularly FWS wetlands, need a local 

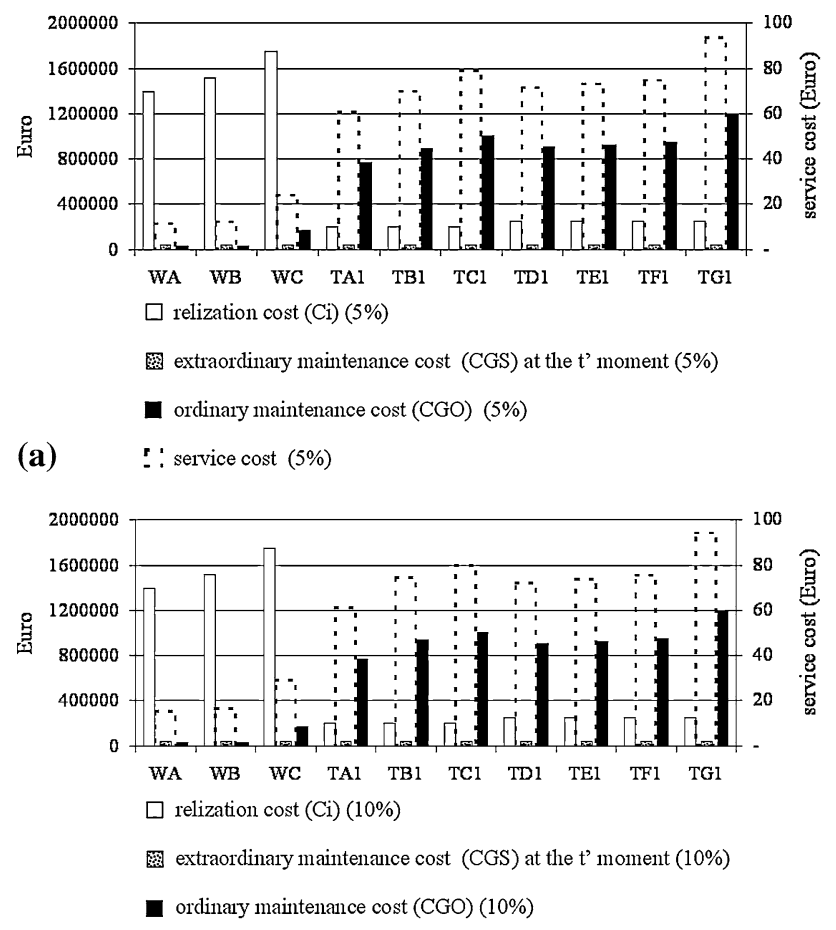

(b) $\quad$ : : service cost (10\%)

Fig. 1 Development $\left(C_{i}\right.$, value on left y-axis), ordinary maintenance $\left(\mathrm{C}_{\mathrm{GO}}\right.$, value on left $\mathrm{y}$-axis), extraordinary maintenance $\left(\mathrm{C}_{\mathrm{GS}}\right.$, value on left $\mathrm{y}$-axis), and the service $\left(\mathrm{C}_{\mathrm{s}}\right.$, value on right $\mathrm{y}$-axis) costs are reported for each equally effective solution selected. The $5 \%$ (a) or $10 \%$ (b) discount rate results are reported. For abbreviations, see Tables 4 and 5

design and construction study that is closely adapted to the context of the environmental conditions. The cost is therefore highly variable and highly dependent on site availability and supply of primary materials.

\section{Ordinary Maintenance Costs}

The ordinary maintenance costs were higher for the traditional wastewater-treatment plant, even for the less expensive solutions. This is because of the need to maintain constant control over the water-treatment stages and sludge disposal: Such control requires constant inputs of

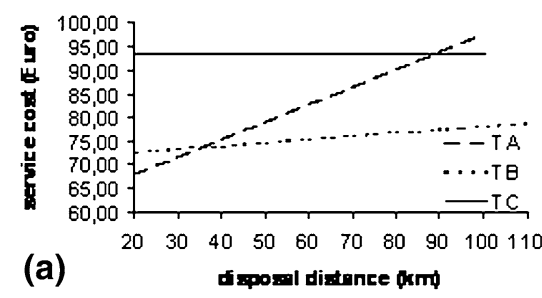

Fig. 2 The function of the service cost of the different technological solutions dealt with by the traveling distance and modality of the sludge disposal. $\mathrm{TA}=$ plant without dehydrator and agricultural technical skill (information), technical components, and energy.

Transport related to disposal was a particularly sensitive cost item: The dehydrator allows a reduction of the sludge volume set against an increase in energy consumption and maintenance costs. Generally, the disposal of solid sludge (with a dehydrator) is less expensive than that of the liquid form (Table 5). Indeed, the companies involved predicted a mean of four journeys per month for the liquid sludge and one every 40 days for the solid. However, when all of the cost items were considered, it was possible to posit a threshold value for the economic benefit related to the use of a dehydrator. The ordinary maintenance costs related to the presence of a dehydrator were lower than the costs needed to transport a larger amount of liquid than solid sludge only for distances greater than $50 \mathrm{~km}$ from the site.

In the case of FWS seminatural wetlands, the artificial inputs of energy and information were very low, and the absence (or modest nature) of mechanical devices implied a reduction in human resources, maintenance, and nonrenewable energy consumption. There was no sludge production.

\section{Service Cost}

The discount rate increase (from 5\% to $10 \%$ ) penalized the solution with the higher initial investment, as it did for the FWS wetlands. Independently of the discount rate, the FWS wetland service cost was always lower than the traditional wastewater plant service cost. At a real operational scale, traditional plants were efficient from the point of view of their construction, but they were not economic in terms of service costs.

The discount rate had a small influence on the critical transport threshold and on the final service cost, whereas travel intensity remained the determining variable for economic performance and the technological solution.

On a conservative assumption, and considering only the most economically viable solutions, three final plants were selected for the cost-effectiveness analyses:

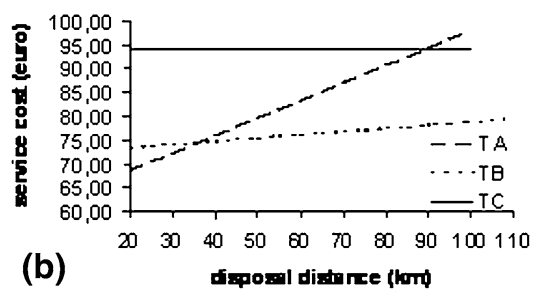

sludge disposal; $\mathrm{TB}=$ plant with dehydrator and agricultural sludge disposal; $\mathrm{TC}=$ plant with dehydrator and competing plant sludge disposal. (a) $\mathrm{i}=5 \%$, (b) $\mathrm{i}=10 \%$ 


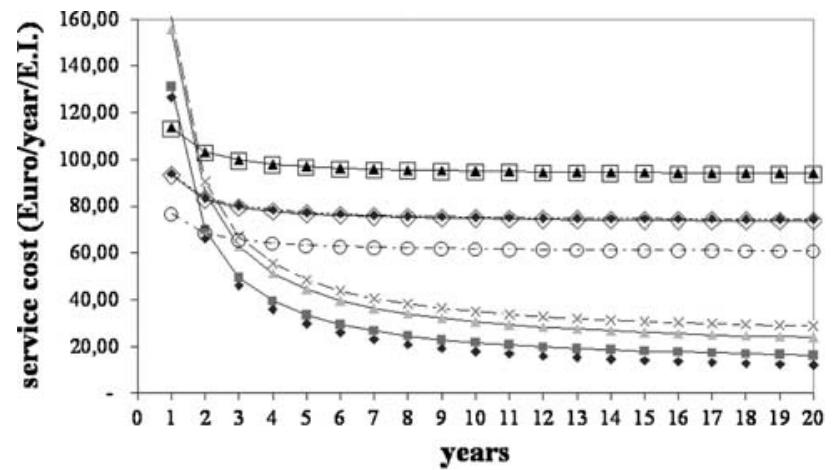

- WB (5\%) $\rightarrow-$ WB $(10 \%)-$ WC $(5 \%)-x-$ WC $(10 \%) \quad \circ \quad$ TA $(5 \%)$

TA $(10 \%) \multimap$ TB $(10 \%)-\ldots$ TB $(5 \%) \quad \square$ TC $(5 \%) \quad \_$TC $(10 \%)$

Fig. 3 A time trend of the service costs estimated for each selected plant. TA = plant without a dehydrator for liquid sludge disposal at a agricultural site within $35.6 \mathrm{~km}$; $\mathrm{TB}=$ plant with a dehydrator for solid sludge disposal at an agricultural site between 35.6-36 and 320 $\mathrm{km} ; \mathrm{TC}=\mathrm{a}$ plant with a dehydrator for solid sludge disposal in a composting plant if agricultural disposal is not possible or the distance from the agricultural site is over $320 \mathrm{~km}$. For WA, WB, and WC explanation, see the materials and Methods section or Table 4

- TA: a plant without a dehydrator for liquid sludge disposal at an agricultural site within $35.64 \mathrm{~km}(i=5 \%)$ or $36.1 \mathrm{~km}(i=10 \%)$

- TB: a plant with a dehydrator for solid sludge disposal at an agricultural site between 35.6 and $320 \mathrm{~km}(i=$ $5 \%)$ or 36.1 and $320 \mathrm{~km}(i=10 \%)$ away

- TC: a plant with a dehydrator for solid sludge disposal in a composting plant, if agricultural disposal is not possible or the distance for disposal is over $320 \mathrm{~km}$

At wastewater-treatment effectiveness parity, the less expensive treatment wetland (WA) had a service cost from sixfold $(i=10 \%)$ to eightfold $(i=5 \%)$ lower than the most expensive of the technological solutions (TC: composition sludge disposal) (Figure 3). The FWS treatment wetland with the higher service cost (WC: plantation, addition of soil and shaping of banks, service road construction, pumping stations, electric system) had a service cost at the settled plant's life span from 2.1-fold $(i=10 \%)$ to 2.5 -fold $(i=5 \%)$ lower than the least expensive of the technological solutions (TA: liquid sludge disposal on attached agricultural fields) (Figure 3).

Estimating the service cost for 20 separate life spans, from 1 to 20 years, a time trend of the service costs was obtained for each plant. All FWS wetland treatment appeared to become economically viable in comparison with the technological alternatives in 1-3 years (Figure 3).

\section{Conclusions}

The results suggested that FWS seminatural wetlands are economically competitive with traditional technological plants for secondary wastewater treatment, given equal depurative effectiveness and independent of the discount rate. Some assumptions on development costs and plant life span had to be made in order to perform the analyses. All assumptions were based on a conservative approach. The three FWS wetland systems were always more economic than the traditional wastewater-treatment plants, with a service cost 2.1-fold to 8-fold lower given the set plant's life span. This was mainly due to the maintenance costs, which were always much lower in seminatural systems, whereas the difference caused by higher development costs was nullified and overturned in 2-3 years (Figure 3).

The higher maintenance costs of biotechnological systems were due to the constant need for monitoring and energy inputs to maintain the required functional processes. On the contrary, FWS seminatural wetlands are multifunctional treatment systems that are similar to natural ecosystems and are therefore self-regulating and in a steady state if within working range - in this case, mainly related to the wastewater loads (hydroperiod and loading rate design).

Disposal was one of the management cost items that most strongly influenced the service cost, yet seminatural wetlands did not produce process discards because matter was recycled within the system. An FWS wetland can have relatively low (presence of inflow and outflow pumping stations) or nil (gravity feed system) electrical energy consumption. All biological processes, even working at higher spatial scales and timescales, utilize solar or endogenous chemical energy.

Only the wastewater purification service was considered in this work. Yet, the financial competitiveness of FWS wetlands increases when considering the reduction of impacts linked to nonrenewable energy consumption and to waste production, to the role in integrated watershed resource management, and to landscape restoration and requalification processes.

Acknowledgments This project was funded by the Ministry of Infrastructures-Venice Water Authority through its concessionary Consorzio Venezia Nuova. We gratefully acknowledge hydraulic data and raw analyses provided by Protecno SRL (Italy) and chemical analyses provided by LabControl SNC (Italy).

\section{References}

Anderson CJ, Mitsch WJ, Nairn RW. (2005) Temporal and spatial development of surface soil conditions at two created riverine marshes. Journal of Environtal Quality 34:2072-2081

Anderson W. (1998) Economic analysis and cost-effectiveness analysis of proposed effluent limitations guidelines and standards for industrial waste combustors. US Environmental Protection Agency Washington, DC

Avsar Y, Tarabeah H, Kimchie S, Ozturk I. (2007) Rehabilitation by constructed wetlands of available wastewater treatment plant in Sakhnin. Ecological Engineering 29:27-32 
Black CA, Wise WR. (2003) Evaluation of past and potential phosphorus uptake at the Orlando Easterly Wetland. Ecological Engineering 21:277-290

Boustany RG, Crozier CR, Rybczyk JM, Twilley RR. (1997) Denitrification in a South Louisiana wetland forest receiving treated sewage effluent. Wetland Ecology and Management 4:273-283

Braskerud BC, T. Hartnik O. Lovstad. 2005a. The effect of the redoxpotential on the retention of phosphorus in a small constructed wetland. Water Science and Technology 51:127-134

Braskerud BC, Tonderski KS, Wedding B, Bakke R, Blanenberg AG, Ulen B, Koskiaho J. 2005b. Can constructed wetlands reduce the diffuse phosphorus loads to eutrophic water in cold temperate regions? Journal Of Environmental Quality 34:2145-2155

Breaux A., Day JW. (1994) Policy considerations for wetland wastewater treatment in the coastal zone: A case study for Louisiana. Coastal Management 22:285-307

Breaux A, Farber S, Day JW. (1995) Using natural coastal wetlands systems for wastewater treatment: an economic benefit analysis. Journal of Environmental Management 44:285-291

Cardoch L., Day JW, Jr., Rybczyk JM, Kemp GP. (2000) An economic analysis of using wetlands for treatment of shrimp processing wastewater: a case study in Dulac LA. Ecological Economics 33:93-101

Craft C, Broome S, Campbell C. (2002) Fifteen years of vegetation and soil development after brackish-water marsh creation. Restoration Ecology 10:248-258

Dass P, Ryuhei I, Iwami N, Mizuochi M, Inamori Y. (2004) Role of emergent macrophyte (Phragmites and Zizania) in nutrient removal and flux of green house gases from wastewater in constructed wetland. In IWA Astee Conference, 26 September-1 October, Avignon, France

Day JW, Arancibia AY, Mitsch WJ Lara-Dominguez AL Day JN, Ko JY, Lane RR, Lindsey J, Lomeli DZ. (2003) Using ecotechnology to address water quality and wetland habitat loss problems in the Mississippi basin: a hierarchical approach. Biotechnology Advances 22:135-159

D.L. vo. n. 152 (Decreto Legislativo 11 maggio 1999 n. 152). (1999) Disposizioni sulla tutela della acque dall'inquinamento e recepimento della direttiva 91/271/CEE concernente il trattamento delle acque reflue urbane e della direttiva 91/676/CEE relativa alla protezione delle acque dall'inquinamento provocato dai nitrati provenienti da fonti agricole."

D.L. vo. n. 152 (Decreto Legislativo 3 aprile 2006 n. 152). (2006) Norme in materia ambientale

Ewel KC, Odum HT. (1984) Cypress swamps, University Press of Florida, Gainesville

Gudger WM, Barker DC. (1993) Banking for the environment. FAO Agricultural Services Bulletin 103. FAO, Rome

Hanley ND, Spash C. (1993) Cost-benefit analysis and the environment. Edward Elgar Publishing, Cheltenham

Healy M, Cawley AM. (2002) Nutrient processing capacity of a constructed wetland in western Ireland. Journal of Environmental Quality 31:1739-1747

Hefting M, Beltman B, Karssenberg D, Rebel K, Van Riessen M, Spijeker M. (2006) Water quality dynamics and hydrology in nitrate loaded riparian zones in the Netherlands. Environmental Pollution 139:143-156

Heinzerling L, Ackerman F. (2002) Cost-benefit analysis of environmental protection. Georgetown Environmental Law and Policy Institute, Georgetown University Press, Washington, DC

Interstate Technology \& Regulatory Council (ITRC). (2003) Technical and regulatory guidance document for constructed treatments wetlands. The Environmental Council of the States, Washington, DC
Jordan TE, Whigham DF, Hofmockel KH, Pittek MA. (2003) Nutrient and sediment removal by a restored wetland receiving agricultural runoff. Journal of Environmental Quality 32:15341547

Kadlec RH, Knight RL. (1996) Treatment wetlands: theory and implementation, Lewis Publishers, Boca Raton, FL

Knowlton MF, Cuvellier C, Jones JR. (2002) Initial performance of high capacity surface flow treatment wetland. Wetlands 22:522527

Ko JY, Day JW, Lane RR, Day JN. (2004) A comparative evaluation of money-based and energy-based cost-benefit analyses of tertiary municipal wastewater treatment using forested wetlands vs. Sand filtration in Louisiana. Ecological Economics 49:331347

Kovacic DA, David MB, Lowell EG, Starks KM, Cooke RA. (2000) Effectiveness of constructed wetlands in reducing nitrogen and phosphorus export from agricultural tile drainage. Journal of Environmental Quality 29:1262-1270

Lorion R. (2001) Constructed wetlands: Passive system for wastewater treatment. Technology status report prepared for the USEPA technology innovation office under a national network of environmental management studies followship

Mitsch WJ, Gosselink JG. (2000) Wetlands, 3rd ed. John Wiley \& Sons, New York

Mitsch WJ, Zhang L, Anderson CJ, Altor AE, Hernandez ME. (2005) Creating riverine wetlands: Ecological succession, nutrient retention, and pulsing effects. Ecological Engineering 25:510 527

Nichols DS. (1983) Capacity of natural wetlands to remove nutrients from wastewater. Journal of Water Pollution Control Federation $55: 495-505$

Nokes RL, Greba CP, Karpiscak MM. (1999) Reduction of enteric organisms in small scale, subsurface flow constructed wetlands. In: Means JL, Hinchee RE (eds.), Wetlands and remediation: Wastewater remediation and treatment. Battelle Press, Columbus, OH. Pages 195-203

Nyakang'o JB, Van Bruggen JJA. (1999) Combination of a well functioning constructed wetland with a pleasing landscape in Nairobi, Kenia. Water Science and Technologies 40:249-256

Pearce DW, Atkinson G, Mourato S. (2006) Cost-benefit analysis and the environment: recent developments Organization for Economic Cooperation and Development (OECD), Paris

Rousseau DPL, Vanrolleghem PA, DePauw N. (2004) Model based design of horizontal subsurface flow constructed wetlands: a review. Water Research 38:1484-1493

Steer D, Aseltyne T, Fraser L. (2003) Life-cycle economic model of small treatment wetlands for domestic wastewater disposal. Ecological Economics 44:359-369

Tchobanoglous G, Burton FL. (1991) Wastewater Eengineering, McGraw-Hill, New York

Tomasinsig E, Vecchiet M, Marangon F, Ceccon L. (2000) Valutazione economica delle tecniche di depurazione delle acque reflue per piccole utenze civili. Genio Rurale 6:15-25

USEPA (United States Environmental Protection Agency). (1993) Constructed wetlands for wastewater treatment and wildlife habitat, 17 case studies. US Environmental Protection Agency, Washington, DC

USEPA (United States Environmental Protection Agency). (2001) Constructed wetlands and wastewater management for CAFOs. US Environmental Protection Agency, Washington, DC

Viessman W, Hammer MJ. (1998) Water supply and pollution control. Addison-Wesley, Menlo Park, CA

Wheeler W. (1998) Cost-effectiveness analysis of effluent limitation guidelines and standards for the centralized waste treatment industry. US Environmental Protection Agency Washington, DC 
Willan A, Briggs A. (2006) Statistical analysis of cost-effectiveness data. John Wiley \& Sons, New York

Wood A. (1995) Constructed wetlands in water pollution control: fundamentals to their understanding. Water Science and Technology 32:21-29

Yang B, Lan CS, Yang CS, Liao WB, Chang H, Shu WS. (2006) Long term efficiency and stability of wetlands for treating wastewater of a lead/zinc mine and the concurrent ecosystem development. Environmental Pollution 143:449-512

Zhang X, Feagley SE, Day JW, Conner WH, Hesse ID, Rybczyk JM, Hudnall WH. (2000) A water chemistry assessment of wastewater remediation in a natural swamp. Journal of Environmental Quality 29:1960-1968 